A wine and cheese supper was served after the meeting and members were then able to walk in the Zoo gardens, by special invitation of the Zoological Society, on what proved to be a beautiful summer evening.

\title{
Whales and Whaling: a Dance of Death
}

\section{Richard Fitter}

The whaling industry and its raw material, the whale stocks of the world, continue their grim Totentanz towards their mutual extinction. The most significant event of the 27th meeting of the International Whaling Commission in London in June, and one of the least publicised, was the Soviet announcement that next season they would have only two instead of three Antarctic expeditions. And, in fulfilment of the classic Parkinsonian theory, the IWC is about to get itself a full-time secretary and new offices in Cambridge just as the industry which provides its raison d'etre has reached the brink of the precipice of its final decline. For the most significant event of all was one which was ignored at the meeting: the current experiments by Norway, West Germany, and other nations into the harvesting of krill. Since harvesting the top of the food chain is always the most uneconomic method of using natural resources, it may well be that in human terms it is more economic for men rather than whales to feed on krill. But there can be no doubt that a thoroughgoing effort to harvest krill would mean the virtual end of the whaling industry, by depriving the great baleen whales of their food. But this prospect did not seem sufficiently real to the IWC mandarins to warrant their discussing it-again a classic reaction to imminent extinction.

The main actual achievement of the 27th meeting was the classification of whale stocks into three categories: Protection Stocks, on which there would be a total moratorium; Sustained Management Stocks, where a strict control of commercial whaling would be exercised; and Initial Management Stocks, where the stock is above the maximum sustainable yield and commercial whaling would be allowed subject to controls to avoid overexploitation (such as has just undoubtedly occurred with the newly exploited minke whale in the Antarctic). The list of devastated whale stocks that have had to be placed in categories one and two, and which are a measure of the crushing failures of the IWC in the past, is shamefully long. If one is prepared to overlook this, then the minor details of this year's deliberations, the fixing of quotas for the few surviving more or less healthy stocks, can be regarded as mildly successful. But should one overlook the fact that an international commission, operating for nearly thirty years has reduced to unexploitable dimensions the stocks of blue and humpback, whales (the gray and right whales were virtually exterminated before they started), and in the past few years has also pushed the fin whale over the brink everywhere except in a single area of the Antarctic, and another in the North Atlantic? Sei whales in two areas and male sperm whales in another area are also 'protection stocks', that splendid euphemism for 'nearly exterminated stocks'. The remaining stocks of fin and sei whales, so recently the mainstay of the whaling industry, are now classed as sustained management stocks, under close control and with small quotas, as are also the minke whale (for which there has only been a quota for one year) in one area of the southern oceans and one of the northern, and sperm whales in certain areas. The only stocks still in a reasonably healthy condition are the 


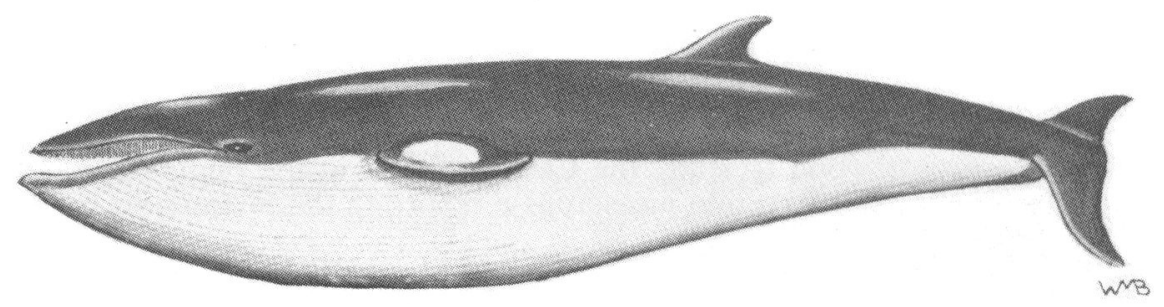

MINKE WHALE

sperm whale in the North Pacific and parts of the southern hemisphere, the minke whale, except for two areas, and Bryde's whale in the North Pacific. How soon will these too qualify first as 'sustained management' and then as 'protection' stocks?

The table gives catch statistics for the last season for the southern oceans, with quotas for the next season for all oceans; previous year's figures are in brackets.

\begin{tabular}{|c|c|c|c|}
\hline \multirow{3}{*}{$\begin{array}{l}\text { Whale } \\
\text { Fin }\end{array}$} & Ocean & Quota 1975/6 & \multirow{3}{*}{$\begin{array}{c}\text { Catch 1974/5 } \\
979(1288)\end{array}$} \\
\hline & Antarctic & $220 \quad(1000)$ & \\
\hline & N Atlantic & $365 \quad-$ & \\
\hline Sei & S Hemisphere & $2230(4000)$ & 3859 (4392) \\
\hline Minke & S Hemisphere & $\begin{array}{l}6810(7000) \\
2550\end{array}$ & $7000-$ \\
\hline Bryde's & N Pacific & 1363 (2000 sei & \\
\hline Sperm, male & S Hemisphere & $5870(8000)$ & $8930(8315)$ \\
\hline $\begin{array}{l}\text { Sperm, female } \\
\text { Sperm, male }\end{array}$ & N Pacific & $\begin{array}{l}4870(5000) \\
5200(6000)\end{array}$ & \\
\hline Sperm, female & & $3100(4000)$ & \\
\hline
\end{tabular}

In addition 11 land stations and five factory ships took 717 (754) fin whales, 2668 (2741) sei whales and $11,087(11,267)$ sperm whales in the $1974 / 75$ whaling season. The drawing is by Captain W. F. J. Mörzer Bruyns from his Field Guide of Whales and Dolphins.

\section{Bird Imports in the UK}

If the Home Secretary insists on hanging on to the Bird Protection Acts as part of his empire, the least he can do on reading the RSPB report, All Heaven in a Rage, is to take the quick and vigorous action which he is entitled to do under the 1954 Act. The report in question is the result of two years' of investigation, and shows that probably at least 600,000 birds are imported into the UK every year, representing nearly ten per cent of a total world trade estimated at $5 \frac{1}{2}$ million birds annually. This vast mass of misery and cruelty-for few overseas dealers care about anything but their profit-could easily be stopped as far as Britain is concerned if the Home Secretary would only use his powers (or hand over responsibility to another Minister) to prohibit the import of all birds not despatched under approved IATA conditions and all those which are on the endangered list in the country of origin. Since 1970 nearly a hundred different species of endangered birds have been imported into Britain. What possible justification can the Home Secretary offer for not having used his powers long ago?

R.F. 